Western North American Naturalist 71(1), (C) 2011, pp. 113-114

\title{
VIRGINIA OPOSSUM (DIDELPHIS VIRGINIANA VIRGINIANA) FROM YAVAPAI COUNTY, ARIZONA
}

\author{
R. Nathan Gwinn ${ }^{1,2}$, Geoffrey H. Palmer ${ }^{1}$, and John L. Koprowski ${ }^{1}$
}

\begin{abstract}
The Virginia opossum (Didelphis virginiana) is the only marsupial native to the United States. In recent times, D. virginiana has expanded its range through natural movements and anthropogenic introductions. Didelphis virginiana has been present in southern Arizona owing to range expansion by the Mexican subspecies (D. v. californica) and anthropogenic introductions of the eastern subspecies (D. v. virginiana). Here, we document the recent collection of an opossum in central Arizona. We also discuss how it possibly moved there and report on its stomach contents at the time of collection.
\end{abstract}

Resumen.-El tlacuache norteño (Didelphis virginiana) es el único marsupial nativo de Estados Unidos. En tiempos recientes, $D$. virginiana ha expandido su área de distribución tanto por movimientos naturales como por introducciones antropogénicas. Didelphis virginiana se ha encontrado en el sur de Arizona debido a la expansión de la subespecie mexicana (D. v. californica) y a introducciones antropogénicas de la subespecie oriental (D. v. virginiana). Aquí documentamos la colecta reciente de un tlacuache en el centro de Arizona. También discutimos cómo podría haber llegado hasta allí e informamos sobre los contenidos de su estómago al tiempo de la colecta.

The Virginia opossum (Didelphis virginiana) is the only marsupial that is native to the United States (Hall 1981). During the last 400 years, the eastern subspecies (D. v. virginiana) has expanded its range north from the Appalachian Mountains to southern Ontario and west to eastern South Dakota (McManus 1974, Gardner 1982). Didelphis v. virginiana was also successfully introduced into California, Oregon, and Washington in the first half of the 20th century (McManus 1974, Long 2003). Subsequent to establishment in the Pacific Northwest, D. $v$. virginiana expanded into southern British Columbia, Canada (Long 2003). In the American Southwest, the Mexican opossum (D. v. californica) was reported in southern Arizona, possibly as early as 1947 (Hoffmeister and Goodpaster 1954). Since then, D. v. californica has been documented in southeastern Arizona, with the most northern documentation coming from the Rincon Mountains east of Tucson in 1999 (Babb et al. 2004). In the 20th century, D. v. virginiana was both purposefully and accidentally introduced into Arizona (Hock 1952, Babb et al. 2004). Despite these introductions, opossum presence has long been considered aberrant in Arizona, and neither subspecies has been considered established in the state (Hoffmeister 1986).

Among the attempts at introduction were those made by S.M. White in northern Arizona (north of Phoenix) between 1927 and 1969 (Babb et al. 2004). White attempted to introduce D. $v$. virginiana from Arkansas to Alpine in Apache County and also to Mayer in Yavapai County (Babb et al. 2004). Given that, at this time, no sightings or specimens of opossums have been reported north of Phoenix, it has been assumed that those attempts failed (Babb et al. 2004). However, we document here the recent collection of an opossum from the town of Mayer in north central Arizona.

On 25 December 2006, a male D. virginiana was shot in a residential driveway on the east side of Mayer, Yavapai County, Arizona. This town is located approximately $118 \mathrm{~km}$ north of Phoenix. Habitat surrounding the town transitions from oak chaparral on hillsides to desert grasslands at lower elevations. Also present in this area are several creeks and washes with deciduous trees, such as Fremont cottonwood (Populus fremontii), Arizona sycamore (Platamus wrightii), Arizona alder (Alnus oblongifolia), boxelder (Acer negundo), and Arizona walnut (Juglans major). We determined that the subspecific status of this individual was D. v. virginiana, based on the light coloration on its face and body, a proportionally shorter tail, $<50 \%$ dark coloration on the tail, and light coloration on the toes and soles of the feet (Gardner 1973, Babb et al. 2004). External measurements of

${ }^{1}$ Wildlife Conservation and Management, School of Natural Resources, Mount Graham Biology Programs, 325 Biological Sciences East, University of Arizona, Tucson, AZ 85721

2E-mail: ngwinn@email.arizona.edu 
this specimen were the following: total length, $82.5 \mathrm{~cm}$; tail length, $35 \mathrm{~cm}$; hind foot length, $8 \mathrm{~cm}$; pinnae length, $5 \mathrm{~cm}$; and weight, $2.5 \mathrm{~kg}$. We deposited the skull of this specimen in the Collection of Mammals, University of Arizona, Tucson (UA\# 27627).

Examination of the specimen's stomach revealed the partial remains of 2 rodent speciesPeromyscus sp. and Reithrodontomys sp. Based on range maps and habitat (Hoffmeister 1986), we could not assign specific status to the Peromyscus; however, of the genus Reithrodontomys, only the western harvest mouse (Reithrodontomys megalotis) occurs in central Arizona. We also observed the partial remains of other dietary items, including the feet and feathers of 2 unidentified passerine birds, scales of a Sceloporus lizard, wings of an ant lion (Neuroptera, Myrmeleontidae), heads of wasps (Hymenoptera, Vespidae), and acorns from a scrub oak (Quercus turbinella).

Documentation of D. v. virginiana north of Phoenix could represent descendants of individuals released by S.M. White that have gone undetected given the nocturnal and secretive habits of this species (Gardner 1982) and the rugged terrain of the area. Alternatively, this individual could represent dispersal from an established population in Phoenix (Babb et al. 2004). The possibility of such dispersal exists given the dispersal ability of the species (McManus 1974, Gardner 1982) and various riparian corridors linking Mayer and Phoenix. Additionally, accidental introduction via commercial shipping, where an individual is inadvertently transported in food shipments, has been documented in Arizona and elsewhere (Long 2003, Babb et al. 2004). Lastly, this individual's presence could be the result of a recent intentional introduction. While collection of one individual does not establish a population in central Arizona, its documentation is an important first step. Regardless of the origin, existence of the nonnative $D$. $v$. virginiana merits further examination to determine the species' status in central Arizona.

We thank C.C. Gwinn for collection and storage of this specimen and for bringing it to our attention; M.E. Bucci and G. Bradley (University of Arizona) for their assistance in preparing the voucher specimen; and M.J. Merrick, N. Cudworth, V.L. Greer, and an anonymous reviewer for reviewing earlier versions of this manuscript.

\section{Literature Cited}

BabB, R.D., D.E. Brown, AND J.L. Childs. 2004. On the status of the opossum (Didelphis virginiana) in Arizona. Journal of the Arizona-Nevada Academy of Science 36:120-126.

GaRDNER, A.L. 1973. The systematics of the genus Didelphis (Marsupialia: Didelphidae) in North and Middle America. Special Publications of the Museum of Texas Tech University 4:1-81.

1982. Virginia opossum. Pages 3-36 in J.A. Chapman and G.A. Feldhamer, editors, Wild mammals of North America: biology, management, and economics. Johns Hopkins University Press, Baltimore, MD.

HaLl, E.R. 1981. The mammals of North America. 2nd edition. John Wiley \& Sons, New York, NY.

Hock, R.J. 1952. The opossum in Arizona. Journal of Mammalogy 33:464-470.

Hoffmeister, D.F. 1986. Mammals of Arizona. University of Arizona Press, Tucson, AZ.

Hoffmeister, D.F., and W.W. Goodpaster. 1954. The mammals of the Huachuca Mountains, southeastern Arizona. University of Illinois Press, Urbana, IL.

LONG, J.L. 2003. Introduced mammals of the world: their history, distribution and influence. CSIRO Publishing, Collingwood, Australia.

McManus, J.J. 1974. Didelphis virginiana. Mammalian Species 40:1-6. 